\title{
THE FAIR (AND QUEER) UNKNOWN IN MALORY'S "THE TALE OF SIR GARETH"
}

\section{Katherine Gubbels}

In the words of one of my students, Sir Gareth is "kind of a weird knight." And, after considering Lot's youngest son and his struggles from kitchen boy to verbal whipping post to impotent lover, I am inclined to agree. After all, while the narrative presents itself as a prototypical "fair unknown" tale, a simple sampling of Gareth scholarship evidences the fact that critics, much like my student, are a bit unsure of what to make of this particular text. Although much of the scholarship focuses on the narrative's source material, or lack thereof, ${ }^{1}$ other studies posit readings of Gareth as a manipulator, a product of alchemy theory, a man on a quest for social stability, and a knight hoping to critique and improve the courtesy of Camelot. ${ }^{2}$ Perhaps some of the confusion arises from seeming contradictions within the piece itself. Indeed, Emily Rebekah Huber points out that Gareth may in fact be read as "flexible." 3 Despite the fact that her study is primarily on Gareth's nameless dwarf and the part he plays in Gareth's progression as a knight, her insight nonetheless points to a certain indefinability, inconsistency, or ambiguity on the part

\footnotetext{
${ }^{1}$ On the origins of Le Morte Darthur, see Eugène Vinaver, ed., "Introduction," in Malory Works, ed. Eugène Vinaver, $2^{\text {nd }}$ ed. (Oxford: Oxford University Press), v-x; Edward Donald Kennedy, "Malory's Use of Hardyng's Chronicle," Notes and Queries 214 (1969) 167-70. On the origins of Gareth's tale, specifically, see P. J. C. Field, "The Source of Malory's Tale of Gareth," in Aspects of Malory, ed. Toshiyuki Takamiya et al. (Cambridge: D. S. Brewer, 1981), 57-70; Wilfred Guerin, “"The Tale of Gareth': The Chivalric Flowering," in Malory's Originality: A Critical Study of Le Morte Darther, ed. R. M. Lumiansky (Baltimore: Johns Hopkins Press, 1964), 99-117; Thomas L. Wright, "On the Genesis of Malory's Gareth," Speculum 57, no. 3 (1982): 569-82; Paul Beekman Taylor, "Myths and Etymologies Behind Malory's Gareth," English Studies 78, no. 6 (1997): 50612; Arnold Sanders, "Sir Gareth and the 'Unfair Unknown'; Malory's Use of the Gawain Romances," Arthuriana 16, no. 1 (2006): 34-46.

${ }^{2}$ Respectively, see Felicia Nimue Ackerman, "'Your charge is to me a plesure': Manipulation, Gareth, Lynet, and Malory," Arthuriana 19, no. 3 (2009): 8-14; Bonnie Wheeler, "'The Prowess of Hands': The Psychology of Alchemy in Malory's 'Tale of Sir Gareth," in Culture and the King: The Social Implications of the Arthurian Legend, ed. Martin B. Shichtman et al. (New York: State University of New York Press, 1994), 163-79; Karen Cherewatuk, "Pledging Troth in Malory's 'Tale of Sir Gareth," JEGP: Journal of English and Germanic Philology 101, no. 1 (2002): 19-40; Ruth Lexton, Contested Language in Malory's Morte Darthur: The Politics of Romance in Fifteenth Century England (New York: Palgrave Macmillan, 2014).

${ }^{3}$ Emily Rebekah Huber, “'Delyver Me My Dwarff!': Gareth's Dwarf and Chivalric Identity," Arthuriana 16, no. 2 (2006), 49.
} 
of Gareth throughout his tale: "The dwarf's capacity to perform [...] drastically different roles reflects, in a sense, Gareth's own flexibility and growth. Gareth has grown as a knight who will work in the kitchen, travel with a 'savage' damsel, repeatedly fight nearly to the death, immerse himself in a love affair, endure separation from his lady, and perform admirably but anonymously in front of Arthur's knights." Building upon Huber's reading, I would like to argue that some of Gareth's "flexibility" is actually the result of his somewhat unusual or even queer performance of the male gender role.

As Judith Butler explains, gender is something performed, something that "ought not to be conceived as a noun or a substantial thing or a static cultural marker, but rather as an incessant and repeated action of some sort." ${ }^{5}$ Thus, if gender is not attached to biological sex, but rather to performed repeated actions, then male characters may perform "feminine" genders and vice versa. Butler explains, "If gender is not tied to sex, either causally or expressively, then gender is a kind of action that can potentially proliferate beyond the binary limits imposed by the apparent binary of sex. ${ }^{6}$ With this in mind, I would like to consider a number of moments in the tale when Gareth performs more of a queer gender role.

In using the term "queer," I refer to all acts that are "subversive of or otherwise resistant to normativity," as defined by Tison Pugh in his book Sexuality and Its Queer Discontents in Middle English Literature. ${ }^{7}$ Seen in this way, a good deal of Gareth's tale is actually a progression of queering rituals, rites, and actions that separate him from normative masculine gender roles. Of course, defining exactly what constitutes normative masculinity in the medieval period is perhaps just as complex as articulating the term "queer." According to Vern L. Bullough, "the most simplistic way of defining [medieval manhood] is a triad: impregnating women, protecting dependents, and serving as a provider to one's family." ${ }^{8}$ Ruth Mazo Karras also engages in the question of what it

\footnotetext{
${ }^{4}$ Huber, “'Delyver Me My Dwarff!"” 52.

${ }^{5}$ Judith Butler, Gender Trouble: Feminism and the Subversion of Identity (New York: Routledge, 2006), 143.

${ }^{6}$ Butler, Gender Trouble, 143.

${ }^{7}$ Tison Pugh, Sexuality and Its Queer Discontents in Middle English Literature (New York: Palgrave Macmillan, 2008), 145.

${ }^{8}$ Vern L. Bullough, "On Being Male in the Middle Ages," in Medieval Masculinities: Regarding Men in the Middle Ages, ed. Clare A. Lees (Minneapolis: University of Minnesota Press, 1994), 34.
} 
means to be a man in the Middle Ages in her book From Boys to Men: Formations of Masculinity in Late Medieval Europe. "In the case of the knight," writes Karras, "masculinity was understood as the opposite of femininity, and dominance over other men was achieved through violence and through control of women." ${ }^{9}$ Dorsey Armstrong, too, points to a connection between the establishment of manhood and the role of women. According to Armstrong, "the homosocial knightly masculine community depends on the feminine for definition - acts of service to ladies help identify knights as legitimate participants in the Round Table community." ${ }^{10}$ As this study will demonstrate, however, even as Gareth engages in typical "masculine" activities of martial prowess, service to ladies, and eventual marriage, he does not succeed in establishing a cohesive, strictly masculine identity.

In fact, the narrative queers Gareth by portraying him-a large, strong male of noble blood-in definitively non-normative positions more often associated with the lower class, women, children, or animals. In occupying these queer roles, Gareth defies typical definitions of masculinity, seemingly in order to more firmly establish his inclusion within the very ideology he transgresses. A similar phenomenon is documented in Pugh's work. According to his study, "when the ideal interpellative process fails to create normative subjects, disciplined subjects can still be constructed through queerness." ${ }^{11}$ Pugh contends that such a construction can occur in one of two ways: voluntary queerness and compulsory queerness. Voluntary queerness, argues Pugh, can be seen in such cross-dressing films as Some Like it Hot, Tootsie, and Mrs. Doubtfire. In each film, the protagonist's voluntary "disavowal of masculine privilege sets the stage for a subsequent reemergence as a better heterosexual male, one more finely attuned to feminine desire and thus at least potentially more successful in heterosexual courtship." 12 "Compulsory queerness," on the other hand, "functions in a similar yet radically different way in that normative masculinity is defined as a goal that can be realized only through queer intercession." 13 In these circumstances, writes Pugh, queerness "is shackled in service of the

\footnotetext{
${ }^{9}$ Ruth Mazo Karras, From Boys to Men: Formations of Masculinity in Late Medieval Europe (Philadelphia: University of Pennsylvania Press, 2003), 11.

${ }^{10}$ Dorsey Armstrong, Gender and the Chivalric Community in Malory's Morte d'Arthur (Gainesville: University Press of Florida, 2003), 17.

${ }^{11}$ Pugh, Sexuality, 13.

${ }^{12}$ Pugh, Sexuality, 14.

${ }^{13}$ Pugh, Sexuality, 15.
} 
creation of proper heterosexual subjects, who find themselves under the forceful sway of compulsory queerness and indoctrinated into heterosexual normativity." 14

Both of these queering processes can be seen in Malory's Gareth; his various queered roles, both voluntary and compulsory, separate him from normative masculinity only to ostensibly strengthen his later reinclusion within that very sphere. Indeed, several other critics have noted a separation and re-inclusion motif apparent in Gareth's tale. One such scholar, Dhira D. Mahoney, examines the theme in relation to Gareth's class. Mahoney writes, "Since inclusion (or reinclusion) results from the demonstration of the hero's lineage or worth, from the confirmation that he is a legitimate member of the knightly class, the initial separation requires the hero's exclusion from that class, either by his ignorance of his birth or by his upbringing in social obscurity due to force of circumstance." ${ }^{15}$ Mahoney is not the only critic to read the tale as one of separation and successful reinclusion. Helen Phillips examines a number of medieval kitchen boys "who represent a threat to the aristocrat's security and honour." 16 According to Phillips, "The narrative [of Malory's Sir Gareth] is marked by recurrent patterns and recurrent contrasts and paradoxes to a degree that can seem comic, yet these foreground the theme of knighthood and what defines it, and at times hold both up to questioning - or at least subject them to a play of questioning - through those contrasts and paradoxes." ${ }^{17}$ At the same time, Phillips explains, just as Malory's narrative questions the legitimacy of knighthood, it ultimately reinforces the status quo. In Phillips' words, "the exercise becomes finally a portrait of gentilesse, not a demonstration of the feats of a kitchen boy. The debate that seems to happen is neutralized." 18

I agree with Phillips in her contention that the tale does appear to suggest the possibility of a subversive element (a lowly kitchen boy could perhaps be as strong and chivalrous as one of noble blood), only to shut down such a prospect fairly early on in the tale as Gareth reveals his

\footnotetext{
${ }^{14}$ Pugh, Sexuality, 15.

${ }^{15}$ Dhira B. Mahoney, "Malory's Tale of Gareth and the Comedy of Class," in The Arthurian Yearbook I, ed. Keith Busby (New York: Garland, 1991), 165.

${ }^{16}$ Helen Phillips, "Bewmaynes: The Threat from the Kitchen," in Arthurian Literature XXVIII: Blood, Sex, Malory: Essays on the "Morte Darthur," ed. David Clark et al. (Cambridge, D. S. Brewer, 2011), 39.

${ }^{17}$ Phillips, "Bewmaynes," 46.

${ }^{18}$ Phillips, "Bewmaynes," 47.
} 
true identity to Launcelot. ${ }^{19}$ The tale also offers another interpretation, however, one in which the would-be subversion apparent in both Mahoney's and Phillips' analyses is not as easily contained. For although Gareth's aristocracy is confirmed fairly early on in the tale for readers (and cemented at Arthur's tournament for the rest of Camelot), the same cannot be said of his gender role. Unlike the subversive elements studied by Mahoney and Phillips, Gareth's queer gender position is not posited and then subsequently shut down or resolved. Rather, Gareth's tale demonstrates an interconnectedness of the normative and the queer, displaying how the time Gareth spends in various queer roles actually serves to shape and inform his later knightly successes, thus calling into question the very "normative" nature of the chivalric institution.

\section{The Boy Who "Never Woll MaKe MaN"}

The tale begins queering Gareth as early as the first page by displaying Lot's youngest son as somehow injured or disabled. Malory writes, "ryght so com into the halle two men well besayne and rychely, and upon their sholdyrs there lened the goodlyest yonge man and the fayreste that ever they all sawe" (177: 23-25). Even in this first encounter, Gareth is dependent upon other men, literally unable to stand on his own. This immediately characterizes Gareth as physically impaired, and hence probably lacking in the physical prowess necessary to establish normative masculinity. After all, as Karras claims, "violence was the fundamental measure of a man because it was a way of exerting dominance over men of one's own social stratum as well as over women and other social inferiors." ${ }^{20}$ Thus, if Gareth is somehow physically disabled, then he is not able to perform the bodily violence necessary of him to prove this own manhood.

Moreover, the narrator even comments that Gareth "fared as he might nat go nothir bere himself but yf he lened upon their [the men's] shuldyrs" (177: 27-28). This is of particular importance as it represents Gareth not as a hero or man of distinction, carried in on the shoulders of his comrades in celebration or honor, but rather as one who is simply unable to support himself. And yet Gareth's physical stature is hardly in question. Gareth himself is "large and longe and brode in the shuldyrs"

\footnotetext{
${ }^{19}$ Sir Thomas Malory, Malory Works, ed. Eugène Vinaver, $2^{\text {nd }}$ ed. (Oxford: Oxford University Press), 181: 35-36. Further references to page and line numbers of this edition will be made in-text.

${ }^{20}$ Karras, From Boys to Men, 21.
} 
(177: 25-26), and moments later he has no problem releasing himself of these men and making his way over to Arthur. Malory's narrator even claims that he does such an act "easyly" (177: 31). This raises the question: if Gareth is not physically disabled in some way, then why is he carried in on the shoulders of two other men as if he cannot support his own weight? It is almost as if Gareth wants to present himself as marginal, or as lacking in normative masculinity in some way, that he is perhaps engaging in an example of Pugh's voluntary queerness.

Additionally, Gareth's queered role is further emphasized in his requests of Arthur. Gareth says, "Now, sire, this is my petycion at this feste, that ye woll geff me mete and drynke suffyciauntly for this twelvemonthe" (177: 41, 178: 1). Although surely food and water are important to any wandering knight, even Arthur cannot believe the simplicity, the meekness, of Gareth's first request. Mahoney also examines this exchange, arguing that "[Gareth's] request for food and drink is lowbred." ${ }^{21}$ Arthur himself implies as much in his comment: "May fayre son, ... aske bettyr, I counseyle the, for this is but a symple askyng; for myne herte gyvyth me to the gretely, that thou arte come of men of worship, and gretly my conceyte fayleth me but thou shalt preve a man of ryght grete worshyp" (178: 3-6). Arthur's implication is that, since he perceives Gareth as a boy of nobility, one likely to "preve a man of ryght grete worship," he should ask for more than mere food and drink, a request Arthur "nevir forbade hit my frynde nother my foo" (178: 7). Nonetheless, Gareth insists that this is all he requires of the richest, most powerful man in all of the land. In this way, the tale presents Gareth as possibly of a lower-class, as argued by Mahoney and others, but also as non-normative. One minute he is carried into the court disabled, the next he is a strong, capable youth, and the next still he is a pauper imploring for a "low-bred" request. While I do not disagree with Mahoney's reading here, I would like to argue that Gareth's request paints him as both poor and child-like. After all, Gareth not only asks for food and drink, but for such accommodations to last for one year. In this way, Gareth requests a kind of gestational period, a set amount of time in which he will reside within the womb of the castle and nourish himself with food and drink.

Arguably, one of the largest examples of Gareth's queered position is evidenced in his relationship with Sir Kay. Almost immediately after Arthur accepts Gareth's requests for food and drink, Kay comments, "I undirtake he is a vylayne borne, and never woll make man - for and he

\footnotetext{
${ }^{21}$ Mahoney, "Malory’s Tale of Gareth," 170.
} 
had come of jantyllmen, he would have axed horse and armour, but as he is, so he askyth" (178: 20-22). Here, Kay directly equates Gareth's request for mere food and drink with an emasculated identity. He supposes him not only the child of a villain, but one that "never woll make man" (178: 20). Perhaps in response to such a request, Kay soon relegates Gareth to the kitchen, adding, "And into the kychyn I shall brynge hym, and there he shall have fatte browes every day that he shall be as fatte at twelve-monthe end as a porke hog" (178: 24-26). This reference to "fattening up" Gareth is particularly interesting as it not only mirrors previous comments coloring this one-year stint as some kind of growing, gestational period, but further serves to characterize Gareth as more beast than man, a sow fattened for the feast. Faye J. Ringel concurs, noting, "Not only is Gareth being fattened up for slaughter, but he is being reduced from a hero to an animal.",22 Although Gareth and Kay see Gareth's stint in the kitchen in two very distinct ways, they are similar in that both interpretations undeniably place Gareth outside of the normative masculine realm of the chivalric court. Whether he is disabled, lowly, childlike, or even a pork hog, in any case, he is certainly not a normative representative of the knightly class.

Furthermore, Gareth's voluntary acceptance of a yearlong stint in the kitchen could be read as queer in and of itself. Despite the fact that the topos of the kitchen-boy is prominent in both English and French chivalric legend, Sarah Gordon points out a number of ways in which Gareth actually transgresses the prototypical characteristics of this particular meme. Firstly, Gordon argues that whereas the kitchen-boy may be a popular representation within the chivalric genre, the kitchenboy-knight is not exactly prolific in Malory. According to Gordon, "Though Sir Kay can be seen in charge of supervising table service, it is unthinkable for members of Malory's court to see other knights toiling in the kitchen." 23 Moreover, Gordon explains that while the presence of noblemen in domestic roles was not unheard of in the fifteenth century, "Gareth is given more menial tasks than would normally be assigned to a gentleman." 24 Thus, while Gareth's job as a kitchen-boy is not out of the ordinary, the specifics of his particular situation are a bit non-normative, or queer.

22 Faye J. Ringel, "Pluto's Kitchen: The Initiation of Sir Gareth," Arthurian Interpretations 1, no. 2 (1987), 36.

23 Sarah Gordon, "Kitchen Knights in Medieval French and English Narrative: Rainouart, Lancelot, Gareth," Literature Interpretation Theory 16 (2005): 200.

${ }^{24}$ Gordon, "Kitchen Knights," 201. 
In fact, one might even argue that his role as kitchen-boy is feminine. In Caroline Walker Bynum's Holy Feast and Holy Fast: The Religious Significance of Food to Medieval Women, she explains that "it is a fact cross-culturally that food is particularly a woman-controlled resource. In the majority of cultures, food preparation is a woman's role. It was certainly so in medieval Europe." 25 Therefore, in accepting Kay's pronouncement of him as a kitchen-boy, Gareth could be aligning himself with a more typically feminine gender position. Bynum explains, "Although the first cookbooks were written by men and the job of chef in the wealthiest households went to males, everyone agreed that the basic social responsibility for food preparation was woman's. ${ }^{26}$ Hence, when Kay proposes that Gareth spend his year working in Arthur's kitchen, he not only implies that Gareth is of a lower social class, but that he is possibly performing the part of the "lesser" gender, that he is feminine.

The tale also presents Gareth as non-normative in both his preparation and consumption of food. For, despite the fact that Gareth technically asks for "mete and drynke" (177: 44, 178: 1), the only food readers hear of him actually consuming is broth. As previously mentioned, Sir Kay distinctly says that Gareth will eat "fatte browes" everyday (178: 24-25). According to the Middle English Dictionary a "browe" is either a "broth, soup, stew," "strips of bread soaked in broth or other liquor," or a "broth or sauce for meat." ${ }^{, 27}$ Thus, while a dish of "fatte browes" may include a fatty sauce or stew prepared for meat, it is, in and of itself, not meat, and therefore significant. As explained by Melissa Raine, the consumption of broth can be read as an indication of class. She writes, "Amongst the hierarchized foodstuffs of the aristocratic table, broth, a liquid form of food, composed in all likelihood of little valued ingredients such as vegetables, and perhaps less palatable animal parts, can be seen as the antithesis of the highly prized roasted flesh."28 Ringel also picks up on the implications of broth: "In many mythologies, boiled food is associated with women, children, or the elderly. Spit-boys can only turn the spits, but heroes get the honor-portion of roasted meat—no swill or sloppy brews for them!" ${ }^{29}$ Accordingly, in allowing

\footnotetext{
${ }^{25}$ Caroline Walker Bynum, Holy Feast and Holy Fast: The Religious Significance of Food to Medieval Women (Berkeley: University of California Press, 1987), 189-90.

${ }^{26}$ Bynum, Holy Feast, 190.

27 "brŏues, n.," Middle English Dictionary, University of Michigan, last modified April 24, 2013, accessed October 13, 2015, http://quod.lib.umich.edu/m/med/.

${ }^{28}$ Melissa Raine, “'Fully Knyghtly He Ete His Mete': Consumption and Social Prowess in Malory's Tale of Gareth," Viator 43, no. 1 (2002): 329.

${ }^{29}$ Ringel, "Pluto's Kitchen," 36.
} 
him the consumption of mere broth, Malory's tale again aligns Gareth with a lower or servant class.

And yet, in addition to this class-based reading, might Gareth's choice of food also queer his gender? According to Bynum, "The history of Western cooking, as reflected in cookbooks, diaries, and memoirs, suggests that 'heavy' food, especially meat, was seen as more appropriate for men and lighter food for women." ${ }^{30}$ In light of this, it seems as if Gareth at once lowers his class and feminizes himself here. What is more, whenever offered the more "masculine" or noble meat, Gareth refuses. Malory explicitly states that both Launcelot and Gawayne offer Gareth "mete and drynke inowe" (178: 44, 179: 1), but he refuses both of them-voluntarily.

Indeed, arguably the most interesting aspect of these roles is the fact that Gareth willingly adopts them. While Gareth apparently also spends time watching other knights joust (179: 9-11), he still readily accepts the more queer positions described above. Such a decision on Gareth's part implies that, like the protagonists of Some Like It Hot, Tootsie, and Mrs. Doubtfire, Gareth believes there is some redeeming virtue to be found in adopting (at least for a year) a more queered role. Although neither the narrator nor Gareth himself articulates his motivations here, one thing is apparent: the fact that Gareth's first year in Arthur's court is spent disassociating himself from normative chivalric masculinity and aligning himself with the more queered roles of the lower class, women, children, and animals.

\section{A QUEER QUEST?}

If the tale presents Gareth as engaging in voluntary queerness in his first year at court, as I contend, then one might argue that he embraces a more normative masculine role in his acceptance of Lyonet's quest. After all, upon Lyonet's arrival, Gareth boldly asks Arthur for both the quest and the title of knight, as decreed by Launcelot. While such actions could be interpreted as more assertive, and thus masculine, it is important to note the ways in which the tale continues to queer Gareth, as well.

For example, soon after agreeing to take on Lyonet's quest, Gareth is queered in his encounters with Launcelot. In his final request from Arthur, Gareth asks "that sir Launcelot du Lake shall make me knyght, for of hym I woll be made knyght and ellys of none. And whan I am

\footnotetext{
${ }^{30}$ Bynum, Holy Feast, 191.
} 
paste I pray you lette hym ryde aftir me and make me knyght whan I require hym" (180: 12-14). Why Gareth does not simply ask Launcelot to knight him right then and there is unclear. Presumably Launcelot is present, for when Gareth leaves the court, the text clearly states that "he [Gareth] cam into the halle and toke his leve of kyng Arthure and sir Gawayne and of sir Launcelot, and prayed hym to hyght aftyr hym" (180: 25-27). Here, however, Gareth specifically asks that Launcelot ride after him. This is intriguing as it places Gareth in the "pursued" position more often associated with the feminine.

What is also odd about Gareth's departure is that he leaves the court without some of his most vital weapons. Malory explains that Garth "had neyther speare nother shylde" (180: 29). Not only is Gareth without his primary weapon, his spear (arguably the most phallic of the knightly accoutrements), he does not even have a shield with which to protect himself. Without such protection, Gareth literally leaves himself open and vulnerable to the penetration of other knights. Therefore, in leaving court without both his spear and his protective shield, Gareth again places himself in a more vulnerable, perhaps even feminine, queered role.

Still, Gareth does not stay spearless for long. Soon after leaving the castle, and subsequently defeating Sir Kay's attacks, Gareth "alyght downe and toke sir Kayes shylde and his speare and sterte upon his horse and rode his way" (181: 2-3). As a result, one might claim that Gareth adopts a more masculine position here. He has, for instance, finally stood up to the torments of Sir Kay, as well as taken the latter's shield and spear, his metaphorical phallus. But despite the fact that Gareth may be demonstrating some attributes of typical masculinity, other aspects of his character at this point in the narrative continue to reflect a certain queer gender association. For example, even though he has left the torments of Kay, Gareth still must use a stolen shield and spear. Importantly, Gareth does not win these items; he and Kay have no agreement regarding an exchange of weapons after the fight. As such, the stolen shield and spear represent a kind of stolen or borrowed masculinity. Moreover, the fact that these are Kay's weapons is significant, as Kay's role in Morte could also be read as queer, in that he supervises the domestic realm and often finds himself in need of rescue.

Gareth's scuffle with Launcelot serves as further proof of his association with a queer role. Shortly after both men joust each other from their respective horses, Gareth "threw his shylde frome hym and profyrd to fyght with sir Launcelot on foote" (181: 9-10). This is a particularly curious action on Gareth's part, as his borrowed shield is the only thing protecting him from the penetration of other knights. Instead, 
here Gareth leaves himself open to Launcelot's thrusts, placing himself in a possibly queered position.

While Morte is filled with scenes of knights penetrating one another in non-sexual ways, I want to examine the possibility of homoerotic tension in this scene. In addition to describing Gareth and Launcelot as boars, "trasyng and traversing and foynyng the mountenaunce of an houre" (181: 11), a phrase Malory often uses, he also adopts descriptors unique to this particular fight. According to the tale, "Launcelot felte hym [Gareth] so bygge that he mervayled of his strengthe, for he fought more lyker a gyanute than a knyght, and his fyghtyng was so passing durable and passing perilous. For sir Launcelot had so much ado with hym that he dred himself to be shamed" (181: 12-16). This scene is remarkable not only for Launcelot's fear of embarrassment, but also because of the emphasis on Gareth's size. The proportions of Gareth's "bygge" body appear to surprise Launcelot. The latter, however, has known Gareth for nearly a year at this point. Surely, Launcelot would have noticed Gareth's large body before this fight. Therefore, one wonders if Launcelot is simply taking note of Gareth's "bygge" body in a way he has not in the past, perhaps in a sexualized manner. The fact that the men may be enjoying each other's physical strength in a homoerotic way is also evident in Gareth's comment that "hit doth me good to fele your [Launcelot's] myght" (181: 19-20). Gareth even says this queer interaction with Launcelot, combative and possibly sexualized, is beneficial to him as a young knight. Whereas the "good" Gareth refers to here could be the physical exertion of the fight, or maybe the experience in and of itself, one might also argue that Gareth is commenting on the benefits of this particularly queer encounter. After all, it is no coincidence that this scene takes place moments before Launcelot grants Gareth his knightly title. As such, the tale seems to imply that there is some kind of connection between queerness and success within the chivalric order.

\section{DOMINATION BY A DAMSEL}

Although Gareth actively seeks out his queer encounters with both Launcelot and Kay, his relationship with Lyonet differs in that Gareth does not appear to have much of a say in the matter. Yes, he initially volunteers to take on Lyonet's quest, but one doubts that poor Gareth has any idea what he is getting into in accepting the mission. Indeed, I want to argue that just as Gareth was engaged in a kind of voluntary queerness in his previous roles with Launcelot and Kay, his association with Lyonet 
might be more accurately described as an example of Pugh's compulsory queerness, a situation in which "normative masculinity is defined as a goal that can be realized only through queer intercession." ${ }^{31}$ The intercessor, in this case, is Lyonet. For, arguably, Gareth is never so emasculated or queered as he is with Lyonet.

And yet, as Gareth rides with Lyonet, one cannot ignore the many colored knights he defeats along the way. If establishing one's dominance over other men is a sign of masculinity, as claimed by Karras, then Gareth is proving himself a man repeatedly. ${ }^{32}$ Interestingly, however, as Gareth defeats the various colored knights, his masculinity is undercut at almost every turn by Lyonet, who continually insists that Gareth's successes are the results of mere luck or coincidence. Regarding the two knights at the bridge, Lyonet says:

Alas, [...] that ever suche a kychyn payge sholde have the fortune to destroy such two knyghtes. Yet thou wenyste thou haste done doughtyly? That is nat so; for the first knyght his horse stumbled and there he was drowned in the watir, and never hit was be thy force nother be thy might. And the last knyght, by myshappe thou camyste behynde hym, and by mysseforutune thou slewyst hym. (183: 29-34)

Here, even feats proving Gareth's abilities as both a man and knight go without recognition. Lyonet simply will not allow Gareth any honor or praise, and in doing so, she undermines his masculinity.

Moreover, Lyonet could be referencing Gareth's gender role in her insults of him, as well. Although many of the derisions hurled toward Gareth by Lyonet are class-based, mocking his kitchen-boy job as a marker of status, I want to suggest that they are also gender-based. As explained earlier, food preparation can be associated with women. Thus, the fact that Lyonet will not let go of Gareth's past association with the kitchen implies that she not only feels less-than-confident having someone of Gareth's presumed class accompany her, but also someone with Gareth's specific gender associations.

Lyonet is determined to continually associate Gareth with the kitchen. In fact, even after Gareth proves himself against both Kay and

\footnotetext{
${ }^{31}$ Pugh, Sexuality, 15.

${ }^{32}$ Karras, From Boys to Men, 11.
} 
Launcelot, Lyonet is still deriding him about his position as a kitchen boy, questioning his abilities as a knight. Her first comments to Gareth directly are:

Thou stynkyst all of the kychyn, thy clothis been bawdy of the grece and talow. What wenyst thou? [...] that I woll alow the for yondir knyght that thou kylde? Nay, truly, for thou slewest hym unhappyly and cowardly. Therefore turne agayne, thou bawdy kychyn knave! I know the well, for sir Kay named the Beawmaynes. What are thou but a luske, and a turner of brochis, and a ladyll-waysher. (182: 612).

Not only does Lyonet allege that Gareth is of the kitchen, but that he is a bad knight, that he beats his enemies unfairly, "unhappily and cowardly," and that his actual skills are nothing more than those of a turner of skewers and washer of ladles. ${ }^{33}$ While such activities may not necessarily designate Gareth as queer, the fact that Lyonet claims that these are Gareth's only skills is significant. According to Karras, a major component of establishing chivalric masculinity is "military prowessexpertise in the use of violence." ${ }^{\prime 34}$ Hence, if Gareth is nothing but a "luske," an idler, who can only turn skewers and wash ladles, he can hardly accomplish the kind of physical violence necessary to establish manhood. ${ }^{35}$

What is perhaps most interesting about Lyonet's emasculating insults, however, is Gareth's response to them. Despite the fact that the Pentecostal Oath requires that Gareth endure Lyonet's torments, it is clear that Gareth himself is not always happy to abide her derisions. He even asks Lyonet to "gyff me [him] goodly langgage" at one point (183: 41). What is more, Gareth is open about the fact that his personal desires do not always coincide with Lyonet's. For example, after fighting the Green Knight, Gareth explains to his groveling enemy, "All is in vayne, $[\ldots]$ for thou shalt dye but yf this damesell that cam with me pray me to save thy lyff," and later, "all this avaylyth the nought buy yf my damesell speke to me for thy lyff" (186: 24-25). Then, after Lyonet finally agrees

33 "broche, n. 1b," Middle English Dictionary, University of Michigan, last modified April 24, 2013, accessed October 13, 2015, http://quod.lib.umich.edu/m/med/.

${ }^{34}$ Karras, From Boys to Men, 25.

35 "luske, n.," Middle English Dictionary, University of Michigan, last modified April 24, 2013, accessed October 13, 2015, http://quod.lib.umich.edu/m/med/. 
to let the Green Knight live, Gareth replies, "Damesell, [...] your charge is to me a pleasure, and at youre commaundemente his lyff shall be saved, and ellis nat" (emphasis mine, 186: 43-44). While Lexton claims that Gareth's fights with the many colored knights "are mostly governed by his self-restraint and compassion, preventing his abnormal strength from becoming savage," ${ }^{36}$ I contend that scenes such as the one described above prove otherwise. After all, here Gareth clearly states that if it were not for Lyonet's wish that the Green Knight live, the latter would surely be dead.

Of course, there is some debate about whether one can take Gareth's words at face value here. As pointed out by Ackerman, this scene can be read as an example in which Gareth "manipulates [Lyonet] into making a request that he is willing to grant. ${ }^{37}$ Nonetheless, I am not sure that Gareth's threats are necessarily idle. Even though it would be against the Pentecostal Oath for Gareth to kill the Green Knight, one needs to keep in mind that he is not always completely faithful to such a pledge. For example, later in the text Gareth quite enthusiastically attempts to engage in premarital sex with Lyoness, another act certainly frowned upon for a strapping young knight.

Thus, Gareth could legitimately want to slay the Green Knight, as he openly expresses. If this is his wish, then he must be going against his own desires when he pardons the Green Knight's life. As such, it appears as if Gareth is governed not by his own self-restraint, but rather by the wishes of his female companion, Lyonet. This same scenario is repeated with the Red Knight. After Gareth defeats the knight, he says, "All this avaylyth nat [...] but if my damesell pray me to save thy lyff" (189: 1011). Although it is Gareth's obligation to follow Lyonet's command, the fact that he chooses to voice his individual dissent only calls attention to the fact that he is uncomfortable with this particular aspect of his chivalric quest. Even though he voluntarily puts himself in queer scenarios with Kay and Launcelot, here Gareth seems less than pleased to follow the wishes of a woman, arguably a somewhat queer role for any medieval man, knight or not.

And yet, there is clearly something to be gained from this position. While it is apparent that Gareth is not always pleased by such an arrangement, he nonetheless explicitly praises this particular queer role and its benefits. He tells Lyonet, "for the more ye seyde the more ye

\footnotetext{
${ }^{36}$ Lexton, Contested Language, 127.

${ }^{37}$ Ackerman, "“Your charge ...,", 8.
} 
angred me, and my wretthe I wrekid upon them that I had ado withal" (191: 11-12). Here, Gareth openly acknowledges that spending time in a subservient, passive position, being endlessly berated by Lyonet, actually helps him become a better knight. This is of particular importance as it illustrates exactly how occupying a queered role aids in Gareth's quest.

\section{THE PRINCESS IS IN ANOTHER CASTLE}

Gareth's queer role is perhaps most apparent in his struggles after his defeat of the many colored knights, in his attempts to make love to Lyoness. For, ultimately, the knight Lyonet conjures to interrupt Gareth and Lyoness's two would-be trysts not only prevents the couple from having sex, but also further emasculates Gareth. According to Malory, "he [the magic knight] smote hym with a foyne thorow the thycke of the thygh, that the wounde was a shafftemonde brode and had cutte a-too many vaynes and synewys" (206: 3-5). Malory's description of Gareth's cut veins and sinews can be read as a metaphoric severing of Gareth's masculinity. Even though Gareth is eventually able to behead the magic knight, "he bled so faste that he might not stonde, but so he leyde hym downe upon his bedde and there he sowned and lay as he had bene dede" (206: 8-10). The fact that Gareth cannot stand and must lie down is a sign of his impotence as a result of the magic knight's cut. Any chance Gareth has of making love to Lyoness has been both literally and figuratively cut away by Lyonet's magic knight. Moreover, Gareth's impotence here is heightened by Lyonet's ability to re-attach the magic knight's head. As the beheading of the magic knight could be read as its own metaphor of castration, Lyonet's ability to rectify the situation positions her as having a power and ability that Gareth clearly does not.

This is not Gareth's only attempt at making love to Lyoness. Ten days after their original would-be tryst, Gareth is apparently healed enough to have another go at it. This time, however, Gareth prepares himself with "his armour and his swerde nygh his beddis syde" (206: 4344). Here, Gareth attempts to equip himself with both protective material, his armor, as well as his own phallic weapon, his sword. In these ways, he attempts to perform a more masculine part, not only by having (presumably male-penetrates-female) sex with Lyoness, but also by protecting himself against penetration (a would-be queer role) and equipping himself with an extra phallus in case of another magic knight intrusion. What is particularly interesting in this scene is the fact that when the magic knight intrudes again, it is Lyoness who attempts to warn and arm Gareth. Lyoness "aspyed an armed knyght commynge towarde 
the bed, and anone she warned sir Gareth. And lightly thorow the good helpe of dame Lyonesse he [Gareth] was armed" (207: 2-4). Therefore, although Gareth again successfully beheads the magic knight, it is not without the help of his female companion, Lyoness, leaving his masculinity in question yet again.

Furthermore, similar to Gareth's first encounter, this second one also results in him being essentially castrated. Malory writes, "Gareth strayned hym so that his olde wounde braste ayen on-bledynge" (207: 7). The reopening of Gareth's first wound not only reaffirms his emasculated position, but also, since Gareth bleeds from his groin, evokes a certain of image of male menstruation. As such, not only is Gareth impotent, but actually feminized. According to the physician at hand, "there was no man that bare the lyff sholde heale hym [Gareth] thorowly of his wounde but yf they heled them that caused the stroke by enchauntemente" (207: 30-32). Thus, Gareth is eternally impotent, unable to play the masculine role in his would-be sex life with Lyoness unless he is healed by Lyonet.

Other scholars have noted Gareth's emasculation as well. Karen Cherewatuk claims that "the sword [of the magic knight] emasculates Gareth through symbolic castration and effeminizes him through penetration.... Gareth takes on the qualities of both female and male, penetrated and would-be penetrator." 38 Megan G. Leitch also analyzes Gareth's feminization in these scenes, examining examples of "beds and bedsheets drenched with male blood in a way that explores the limits of knightly identity." ${ }^{39}$ According to Leitch such a motif "inverts the normal gendered view of the nature of blood flow to signal threats to or loss of the individual knight's social status." ${ }^{40}$ Moreover, "the location for the bloodshed is [...] conventionally gendered, with the men's blood linked to the battlefield and women's blood linked to the bedroom." ${ }^{\text {"41 }}$ Thus, the text portrays Gareth as "temporarily emasculated when he is repeatedly attacked by Lyonet's magical knight." ${ }^{42}$

Why Lyonet continues to emasculate Gareth, however, is puzzling. Miriam Rheingold Fuller argues that Lyonet is Gareth's "mentor and

\footnotetext{
${ }^{38}$ Cherewatuk, "Malory's Thighs," 42.

${ }^{39}$ Megan G. Leitch, "(Dis)Figuring Transgressive Desire: Blood, Sex, and Stained Sheets in Malory's Morte Darthur," in Arthurian Literature XXVIII, ed. David Clark et al. (Cambridge: D. S. Brewer, 2011), 21.

${ }^{40}$ Leitch, "(Dis)Figuring," 21.

${ }^{41}$ Leitch, "(Dis)Figuring," 24.

${ }^{42}$ Leitch, “(Dis)Figuring," 34.
} 
guide," his "most effective teacher and one of his greatest friends." 43 Indeed, few can argue with the fact that Lyonet's treatment of Gareth, at times both violent and cruel, nonetheless benefits him in his journey. Furthermore, it seems that such treatment not only benefits Gareth, but everyone, or at least everyone in the courtly community. After Gareth's first encounter with the magic knight, Lyonet says "all that I have done I woll avowe hit, and all shall be for your worship and us all" (206: 37-38). Similarly, after Gareth's second tussle with the magic knight, Lyonet again repeats, "I have nothyinge done but I woll avow hit, and all that I have done shall be to your worship and to us all" (207: 27-28). According to Lyonet, her deeds not only aid in Gareth's personal growth, but also somehow strengthen and redeem all of the court. It is clear that, at least in Lyonet's opinion, Gareth's queered role is necessary in order for him to become the kind of knight whose life will benefit "us all."

As helpful as Lyonet's words are to both Gareth and humanity, Gareth is hardly pleased with the actions of Lyonet's castrating magic knight. Once Gareth hears of the tournament Lyoness has arranged with the Knights of the Round Table, he is understandably disappointed. He exclaims, "I have bene so sore wounded with unhappy-nesse sitthyn I cam into this castell that I shall nat be able to do at that turnemente lyke a knyght; for I was never thorowly hole syn I was hurte" (211: 38-41). Interestingly, here Gareth bemoans his wound's effect on his abilities as a knight. Additionally, he describes himself as not "thorowly hole" (211: 40). Here, Gareth's words refers not only to the physical gash in his body, his wound, but also to his incomplete masculinity. While he has a female love-object in Lyoness, he still cannot perform as a normative male and penetrate her sexually. Furthermore, although he is a knight who has won a great deal of honor and respect, successfully completing his quest goal of defeating the Red Knight, he cannot perform the typical masculine role and win the tournament. Both of these inabilities are significant blows to Gareth's would-be masculinity, as both sexual performance $^{44}$ and physical prowess ${ }^{45}$ are crucial elements to medieval masculinity. The fact that Gareth can only regain each of these capabilities through Lyonet's magic is only further emasculating. He is a man who can assert his masculinity only through the aid of a woman.

\footnotetext{
${ }^{43}$ Miriam Rheingold Fuller, "Method in Her Malice: A Reconsideration of Lyonet in Malory's Tale of Sir Gareth," in Fifteenth-Century Studies: Volume 25, ed. William C. McDonald (New York: Camden House, 2005), 253.

${ }^{44}$ Bullough, "On Being a Male," 41.

${ }^{45}$ Karras, From Boys to Men, 25.
} 
This theme is further emphasized in Gareth's performance in the actual tournament. Despite the fact that Lyonet's healing balms leave Gareth "never so freyshe nother so lusty as he was tho" (212: 2), he still must use Lyoness's ring in order to dominate in battle. The ring ensures that not only will Gareth remain disguised, but also protected. As Lyoness explains, "who that beryth this rynge shall lose no bloode" (214: 2-3). Leitch also seizes upon this moment. She claims, "[Gareth] must rely upon the supernatural aid of both Lyonett and Lyonesse" in the former's medical assistance and the latter's magic ring. ${ }^{46}$ According to Leitch, "both sisters, in succession, wield power over Gareth's blood flow - causing it, staunching it, and preventing it. The women control his body and its boundaries, renegotiating gender power relations through (male) blood." 47 Thus, in both scenarios, Gareth is dependent on women - hardly a normative masculine role.

Of course, many knights, including Arthur himself, have found themselves benefitting from the aid of a magical woman and/or her enchanted love token. Still, the timeline of events here is significant. Even though Gareth has already conquered the many colored knights at this point in the narrative, he has most recently failed at sexual intercourse - twice! This is a problem for Gareth in terms of establishing normative masculinity. Not only has Gareth failed at the male sexual role, a key component of maleness according to Bullough, he has also undercut his previous displays of physical prowess, for, as Bullough explains, "It is almost as if the 'superiority of the male' has to be demonstrated continually or else it will be lost." ${ }^{\text {" }}$ Therefore, despite the fact that Gareth has established a kind of normative masculinity in his victories against the many colored knights, he loses a degree of this masculinity when he cannot perform sexually with Lyoness. His masculinity is even further eroded when he needs Lyonet's help to be healed, and Lyoness' ring to succeed at the tournament. In short, while any one of these events could be read as non-normative, the succession of all three is a damning blow toward any chance Gareth has of establishing and maintaining normative masculinity.

\footnotetext{
${ }^{46}$ Leitch, "(Dis)figuring," 35.

${ }^{47}$ Leitch, “(Dis)figuring," 35-36.

${ }^{48}$ Bullough, "On Being a Male," 41, 34.
} 


\section{HAPPILY EVER AFTER?}

Ostensibly, one might argue that shortly after the tournament, Gareth experiences a change of luck, as he reunites with his brother, Gawayne, and finally marries Lyoness. Many see this as the natural conclusion to the tale's separation and re-inclusion motif; the tale is a "demonstration and affirmation of true nobility." 49 Gareth's true lineage and worth are acknowledged by the court, and he finally gets the girl. I would like to suggest that Gareth's queer roles are not as contained or resolved as they first appear, however.

When Lyonet interrupts Gareth and Gawayne's battle, she exclaims, "Sir Gawayne! Leve they fyghtynge with thy brothir, Sir Gareth" (221: 43). This is a pivotal moment in the tale, for not only is Gareth's true identity finally revealed to Gawayne, but also the latter welcomes him into the chivalric fold. As Gawayne welcomes his "brothir," he embraces Gareth not just as a blood relative, but also as a member of his chivalric family, his community of knights. Gawayne even says, "I ought of ryght to worship you, and ye were nat my brother, for ye have worshipte kynge Arthure and all his courte, for ye have sente mo worshypfull knightes this twelve-monthe than fyve the beste of the Rounde Table hath done excepte sir Launcelot" (222: 12-16). This is of particular importance as Gawayne explicitly says that Gareth's new-found honor is the result of the knights he sent back to the Round Table, an action Gareth almost did not do. If Gareth had followed his wishes and simply killed these knights, he would not have been granted this respect. As discussed above, it was Lyonet who insisted that Gareth spare the knights' lives and instead send them to Arthur's court. Ergo, it was Gareth's subservience to Lyonet's wishes, arguably a queer position, that affords him this honor. Of course, as dictated by the Pentecostal Oath, knights are expected to follow the order of their lady: "allwayes to do ladyes, damesels, and jantilwomen and wydowes socour" (75: 41-2). Nonetheless, this obedience, in combination with Gareth's other queer association, highlights the particular ways in which queerness can lead to chivalric success. Instead of independently proving himself worthy of his familial name, like most fair unknown knights, Gareth's tale seems to imply that one must embrace a less-than-normative role in order to be successful, that an adoption of a certain queer position is beneficial for achieving both opposite-sex coupling and inclusion in the chivalric order.

\footnotetext{
${ }^{49}$ Mahoney, "Malory’s Tale of Gareth," 173.
} 
Gareth's periods of gender digression are not without merit or purpose, then. This is especially apparent at Gareth and Lyoness's wedding celebration, as each of Gareth's defeated knights comes to help at the reception (224:38-225:16). These knights arrive not only to do honor to Gareth and his marriage, however; they also wish to participate in a number of service tasks including chamberlain, chief butler, chief server, and wine server. "Though these are higher positions in the household than Gareth's former rank," explains Gordon, "they in a sense pay homage to his earlier kitchen servitude." ${ }^{\circ}$ Although the knights might be simply demonstrating a respect for service, one of Gareth's specialties according to Lexton, ${ }^{51}$ they are still choosing to take on roles well below their social status, an abnormal or queer decision in and of itself. What is of further interest is Gareth's response to their requests. When Pertolope asks to work as Gareth's “chameirlayne," Gareth says, "with good wyll [...] syth hit lyke you to take so symple an offyce" (224: 38-40). Here, Gareth explains that he approves of Pertolope's request because, "syth," it pleases him (Pertolope) to take on such a lowly job. Gareth displays, then, his approval of other knights taking on nonnormative duties. Moreover, in response to the serving requests of the Rede Knight, Persaunte of Inde, and the Duke de la Rouse, Gareth approves each and says, "I wot well [...] and hit were bettir" (225: 1-2, 7, 12). This comment is of particular interest as it can be read in a number of ways. While Gareth could mean that he wishes the tasks were better, or more apt for such knightly men, he might also be expressing his hope that such positions be viewed or considered "bettir," that is, more acceptable and noble. Gareth may be asking that the court, including Kay, view men wishing to adopt more unusual or queer roles in a kinder, even honorable light.

As such, one might read Gareth's enthusiastic support of the knights' request as his endorsement of non-normative positions. After all, as demonstrated above, it appears as if Gareth's queered roles have helped him greatly in his quest for chivalric success. We must then ask whether Gareth is unique in this regard, or is he perhaps representative of a larger phenomenon embedded within chivalric literature? As Gordon points out, there are a number of non-normative kitchen knights, ${ }^{52}$ and one can even argue that Malory's own La Cote Male Tayle and Launcelot are queered at certain points in Morte Darther. I would even

\footnotetext{
${ }^{50}$ Gordon, "Kitchen Knights," 208.

${ }^{51}$ Lexton, Contested Language, 109-39.

${ }^{52}$ Gordon, "Kitchen Knights," 189-212.
} 
contend that Gawain of Gawain and Green Knight is queered in his obedience to both Lady and Lord Bertilak. ${ }^{53}$

Gareth's tale, then, appears to be an illustrative example of a possibly larger paradigm. Like the narratives of the knights mentioned above, Gareth's tale portrays him in a number of non-normative, queer roles, both voluntary and compulsory. Moreover, his queerness is presented in such a way that it seems necessary, or at least beneficial, to his position as a knight. Thus, if Gareth's story is "a view of the ideal progression of a knight," as Armstrong contends, ${ }^{54}$ then one must wonder what part his various queered episodes play in such a progression. Indeed, if one analyzes the narrative in light of Pugh's definition of queerness as that which is "subversive of or otherwise resistant to normativity," the tale queers Gareth in a number of different ways. ${ }^{55}$ This queerness is particularly noteworthy considering the fact that Gareth's story may be the only one original to Malory. ${ }^{56}$ As such, one might read Gareth's tale as Malory's investigation of normative masculinity, especially in relation to the chivalric code. What does it mean that Malory's only unique creation, a knight whose progression is considered "ideal," is at times described as disabled, low-class, childlike, effeminate, and emasculated? I would like to suggest that perhaps Malory offers an alternative vision of chivalric masculinity in Gareth, one that may be a bit more realistic, possibly even inconsistent, but one that is certainly queer.

\section{Memphis College of Art}

\footnotetext{
${ }^{53}$ I examine periods of queering as a part of the chivalric process in my dissertation, “"An Uncouth Love': Narrative Digression and Queer Transgression in Medieval and Early Modern Romances"

${ }^{54}$ Armstrong, Gender, 129.

${ }^{55}$ Pugh, Sexuality, 145.

${ }^{56}$ Guerin, Wright, and Taylor all argue for Malory's originality (at least partially) in his creation of Gareth's tale. See note 1.
} 


\section{Bibliography}

Ackerman, Felicia Nimue. "'Your charge is to me a plesure': Manipulation, Gareth, Lynet, and Malory." Arthuriana 19, no. 3 (2009): 8-14. http://dx.doi.org/10.1353/art.0.0061

Armstrong, Dorsey. Gender and the Chivalric Community in Malory's Morte d'Arthur. Gainesville: University Press of Florida, 2003.

Bullough, Vern L. "On Being Male in the Middle Ages." In Medieval Masculinities: Regarding Men in the Middle Ages, edited by Clare A. Lees, 31-45. Minneapolis: University of Minnesota Press, 1994.

Butler, Judith. Gender Trouble: Feminism and the Subversion of Identity. New York: Routledge, 2006.

Bynum, Caroline Walker. Holy Feast and Holy Fast: The Religious Significance of Food to Medieval Women. Berkeley: University of California Press, 1987.

Cherewatuk, Karen. "Malory's Thighs and Launcelot's Buttock: Ignoble Wounds and Moral Transgression in Morte Darthur." In Arthurian Literature XXXI, edited by Elizabeth Archibald and David F. Johnson, 35-59. Cambridge: D. S. Brewer, 2014.

. "Pledging Troth in Malory's 'Tale of Sir Gareth." JEGP: Journal of English and Germanic Philology 101, no. 1 (2002): 19-40.

Field, P. J. C. "The Source of Malory's Tale of Gareth." In Aspects of Malory, edited by Toshiyuki Takamiya and Derek Brewer, 57-70. Cambridge: D. S. Brewer, 1981.

Fuller, Miriam Rheingold. "Method in Her Malice: A Reconsideration of Lyonet in Malory's Tale of Sir Gareth." In Fifteen-Century Studies: Volume 25, edited by William C. McDonald, 253-67. New York: Camden House, 2005.

Gordon, Sarah. "Kitchen Knights in Medieval French and English Narrative: Rainouart, Lancelot, Gareth." Literature Interpretation Theory 16 (2005): 189-212.

http://dx.doi.org/10.1080/10436920590946822

Guerin, Wilfred. "The Tale of Gareth': The Chivalric Flowering." In Malory's Originality: A Critical Study of Le Morte Darthur, edited by R. M. Lumiansky. 99-117. Baltimore: John Hopkins Press, 1964.

Huber, Emily Rebekah. “'Delyver Me My Dwarff!': Gareth's Dwarf and Chivalric Identity." Arthuriana 16, no. 2 (2006): 49-53. http://dx.doi.org/10.1353/art.2006.0072 
Karras, Ruth Mazo. From Boys to Men: Formations of Masculinity in Late Medieval Europe. Philadelphia: University of Pennsylvania Press, 2003.

Kennedy, Edward Donald. "Malory's Use of Hardyng's Chronicle." Notes and Queries 214 (1969): 167-70.

Leitch, Megan G. “(Dis)Figuring Transgressive Desire: Blood, Sex, and Stained Sheets in Malory's Morte Darthur." In Arthurian Literature XXVIII, edited by David Clark and Kate McClune, 21-38. Cambridge: D. S. Brewer, 2011.

Lexton, Ruth. Contested Language in Malory's Morte Darthur: The Politics of Romance in Fifteenth Century England. New York: Palgrave Macmillan, 2014. http://dx.doi.org/10.1057/9781137353627

Mahoney, Dhira B. "Malory's Tale of Gareth and the Comedy of Class." In The Arthurian Yearbook, I, edited by Keith Busby, 165-93. New York: Garland, 1991.

Malory, Sir Thomas. Works, edited by Eugène Vinaver. Oxford: Oxford University Press, 1971.

Middle English Dictionary. Middle English Compendium. University of Michigan. http://quod.lib.umich.edu/m/med/.

Phillips, Helen. "Bewmaynes: The Threat from the Kitchen." In Arthurian Literature XXVIII: Blood, Sex, Malory: Essays on the Morte Darthur, edited by David Clark and Kate McClune, 39-55. Cambridge: D. S. Brewer, 2011.

Pugh, Tison. Sexuality and Its Queer Discontents in Middle English Literature. New York: Palgrave Macmillan, 2008. http://dx.doi.org/10.1057/9780230610521

Raine, Melissa. “Full Knyghtly He Ete His Mete': Consumption and Social Prowess in Malory's Tale of Gareth." Viator 43, no. 1 (2002): 323-37. http://dx.doi.org/10.1484/J.VIATOR.1.102553

Ringel, Faye J. "Pluto's Kitchen: The Initiation of Sir Gareth." Arthurian Interpretations 1, no. 2 (1987): 29-38.

Sanders, Arnold. "Sir Gareth and the 'Unfair Unknown'; Malory's Use of the Gawain Romances." Arthuriana 16, no. 1 (2006): 34-46. http://dx.doi.org/10.1353/art.2006.0054

Taylor, Paul Beekman. "Myths and Etymologies Behind Malory's Gareth." English Studies 78, no. 6 (1997): 506-12. http://dx.doi.org/10.1080/00138389708599100 
Vinaver, Eugène. "Introduction." In Works, by Sir Thomas Malory, edited by Eugène Vinaver, $2^{\text {nd }}$ ed., v-x. Oxford: Oxford University Press, 1971.

Wheeler, Bonnie. “'The Prowess of Hands': The Psychology of Alchemy in Malory's 'Tale of Sir Gareth." In Culture and the King: The Social Implications of the Arthurian Legend, edited by Martin B. Shichtman and James P. Carley, 163-79. New York: State University of New York Press, 1994.

Wright, Thomas L. "On the Genesis of Malory's Gareth." Speculum 57, no. 3 (1982): 569-82. http://dx.doi.org/10.2307/2848694 